\title{
Cyanobacteria distribution and abundance in the Spanish water reservoirs during thermal stratification
}

\author{
C de Hoyos ${ }^{(1)}$ A. I. Negro (2) \& J. J. Aldasoro ${ }^{(3)}$
}

(1) CEDEX. Paseo bajo de la Virgen del Puerto, 3. 28005 Madrid.

(2) Area de Ecología. Facultad de Biología. Universidad de Salamanca. Campus Miguel de Unamuno. 37071 Salamanca.

(3) Real Jardín Botánico. C.S.I.C. Plza. De Murillo, 2. 28014 Madrid.

\begin{abstract}
A study of the distribution and abundance of Cyanobacteria in 47 Spanish water reservoirs revealed a significant correlation between these algae and total phosphorus in the water. Cyanobacteria distribution was related to the N:P ratio, and they were scarce when the atomic ratio of total inorganic N/ total P exceeded 50. The N:P ratio was influenced by the geology of the catchment, and it was lower in the solute-poor waters of western Iberian Peninsula, where Cyanobacteria were more abundant (mainly the Nostocales). Therefore, this area would be more prone to present problems derived from Cyanobacteria proliferation than the eastern part of Spain. In the studied reservoirs we have recorded 45 taxa of Cyanobacteria, many of which can produce toxins. A comparison of our results with those of previous studies served to conclude that Cyanobacteria have increased both in biomass and species number in Spanish reservoirs.
\end{abstract}

Key words: Cyanobacteria, Spanish water reservoirs, N:P ratio, Geological substrata.

\section{RESUMEN}

El estudio de la distribución y abundancia de Cianobacterias en 47 embalses españoles reveló una correlación significativa entre estas algas y la concentración de fósforo total en el agua. La distribución de Cianobacterias estuvo relacionada con el cociente N:P, siendo generalmente poco abundantes cuando la relación atómica $N$ inorgánico total / P total fue superior a 50. La relación N:P en el agua está influenciada por la geología de la cuenca, y fue menor en las aguas menos mineralizadas del oeste de la Península Ibérica, donde las cianobacterias fueron más abundantes (especialmente las nostocales). Por lo tanto, esta zona de la península Ibérica sería más propensa a sufrir problemas relacionados con la proliferación de Cianobacterias que la zona este de España. En los embalses estudiados hemos encontrado 45 taxones de Cianobacterias, muchas de las cuales pueden producir toxinas. La comparación de nuestros resultados con estudios realizados previamente sirvió para concluir que en los embalses españoles se ha producido un aumento del número de especies y de la biomasa de Cianobacterias

Palabras clave: Cianobacterias, Embalses españoles, Relación N:P, Geología del sustrato.

\section{INTRODUCTION}

Cyanobacteria is a group of photosynthetic prokaryotic organisms which can sometimes produce "blooms". Blooms are events of explosive growth, which occur mainly during the summer and early autumn months; they are dense accumulations of cells at the surface of eutrophic and mesotrophic lakes and water reservoirs (Reynolds, 1987). This, along with the fact that many Cyanobacteria species produce toxins, harmful both to humans and animals, has focused the interest of water-resources and water-quality managers on these organisms (Sivonen \& Jones, 1999).

There have been several hypothesis presented concerning the relationship between environmental conditions and cyanobacteria abundance (Reynols \& Walsby, 1975; Smith, 1983; Reynolds, 1987; Paerl, 1988; Steinberg \& Hartmann, 1988; Canfield et al., 1989; Shapiro, 1990; Blomqvist et al., 1994; Reynolds Petersen, 2000; Bianchi et al, 2000; De Hoyos et al., 2000). 
High temperature and physical stability of the water column optimize the growth and persistence of cyanobacteria (Reynols \& Walsby, 1975; Paerl, 1988). Low water-retention time also represents the advantage of cyanobacteria over other algae (De Hoyos, 1996; De Hoyos et al., 2000). Under physically favorable conditions, $\mathrm{N}_{2}$-fixing cyanobacteria should dominate phytoplankton communities faced with nitrogen limitation (Paerl, 1988). Smith (1983) using data from a variety of lakes, has established criteria for N:P boundaries below which cyanobacterial dominance might be expected. Moreover, cyanobacteria are more efficient at obtaining $\mathrm{CO}_{2}$ from low concentrations than other algae (Shapiro, 1990; Reynolds \& Petersen, 2000) so they will outcompete other phytoplankton during periods when $\mathrm{pH}$ is high.
Nitrogen and phosphorus concentration in water depends on antropogenic-nutrient inputs but it is also related to the geology of the catchments. When calcium is abundant, it is able to remove phosphate from the water by precipitation in the form of hydroxyapatite (Armengol et al., 1991). The Iberian Peninsula has two different geological areas (siliceous rocks in the west and sedimentary rocks in the east), which are of interest in this kind of studies because its two areas have different mineral composition but are similar in other environmental factors. In Spain the chemical weathering of rocks and soils is the main factor determining surface-water composition (Margalef, 1976; Estrada, 1978; Armengol et al., 1991; Riera et al., 1992). The $\mathrm{N}_{-} \mathrm{NO}_{3}-/ \mathrm{P}_{-} \mathrm{PO}_{4}{ }^{3-}$ atomic ratio is lower in the siliceous region than in the area dominated by sedimentary rocks (Margalef, 1976).

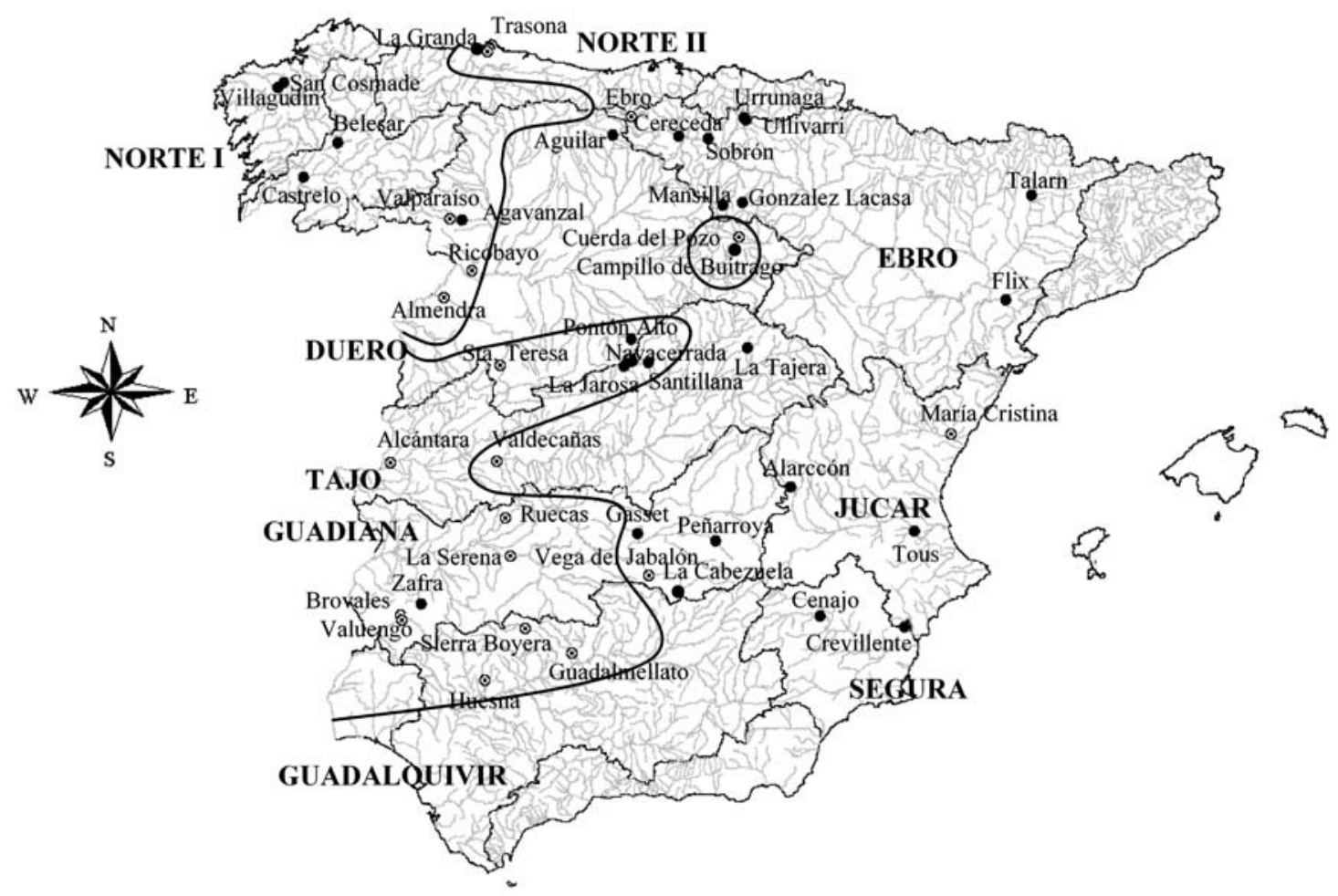

Figure 1. Distribution of the studied water reservoirs in administrative Spanish water basins. Two types of reservoirs are represented: those with Cyanobacteria biovolume higher than $200 \mathrm{~mm}^{3} / \mathrm{m}^{3}(\odot)$ and those with lower biovolume $(\bullet)$. The broken line separates the $\mathrm{W}$ areas with rocks of low solubility from those with rocks of high solubility. Distribución de los embalses estudiados en las cuencas hidrográficas en las que se divide administrativamente el territorio español. Se representan dos tipos de embalses: los de biovolumen de cianobacterias mayor de $200 \mathrm{~mm}^{3} / \mathrm{m}^{3}(\odot)$, y los de biovolumen menor $(\bullet)$. La linea de puntos separa las zonas con rocas de baja solubilidad situadas en el oeste de las zonas con rocas de alta solubilidad. 
The Spanish water reservoirs are often affected by Cyanobacteria blooms. However, there are no papers globally addressing the quantity and distribution of this algae group in Spain. There are some reports of studies on phytoplankton in water reservoirs scattered all over Spain (Planas, 1975; Margalef et al., 1976; Sabater \& Nolla, 1991; Riera et al., 1992) other ones which focus on a group of water reservoirs in one region (Toja, 1984; Armengol et al., 1990; Dasí et al, 1998 ) and others only on one reservoir (VidalCelma, 1969; Toja, 1980; Ramón \& Moyá, 1984; Alvarez Cobelas \& Arauzo, 1994; Arauzo \& Álvarez Cobelas, 1994; Negro et al., 2000). Most of these studies are not recent. It seems that an up-to-date study on the occurrence and abundance of Cyanobacteria, their relationships with environmental conditions and problems related to this group of algae in Spanish water reservoirs is necessary.

\section{MATERIALS AND METHODS}

We surveyed 47 water reservoirs distributed all over Spain, covering most of the administrative Spanish water basins (Fig. 1, Table 1). Samples used in this study were taken in summer or autumn between 1999 and 2001 (Table 1) at one point near the dam. In 37 reservoirs, phytoplankton samples and water samples for chemical analysis were taken at $2 \mathrm{~m}$ depth.

Phytoplankton samples were immediately fixed with Lugol's solution and later, in the laboratory, were sedimented and counted under an inverted microscope using Utermöhl's method. The recounting was carried out at 400 $\times$ and $1000 \times$, counting the cell number sufficient to obtain significant results (Sournia, 1978). Cyanobacteria determination was done according to the following authors: Geitler, 1932; Desikachary, 1959; Komárek \&

Table 1.- List of the reservoirs studied, administrative Spanish water basin where they are located, type of geological substratum (HS: High solubility rocks; LS: low solubility rock), average depth, and sampling date. Lista de los embalses estudiados, cuenca hidrográfica en la que están situados, tipo de roca del sustrato (HS: rocas muy solubles; LS: rocas poco solubles) profundidad media, y fecha del muestreo.

\begin{tabular}{lccrl}
\hline Reservoir & Administrative water basin & Geological substratum & Average depth (m) & Sampling date \\
\hline Ebro & Ebro & HS & 8.64 & September 1001 \\
Mansilla & Ebro & HS & 27.64 & September 1999 \\
Gonzalez Lacasa & Ebro & HS & 21.71 & August 1999 \\
Sobrón & Ebro & HS & 7.14 & July 1999 \\
Cereceda & Ebro & HS & 2.86 & July 1999 \\
Urrunaga & Ebro & HS & 9.17 & October 2000 \\
Ullivarri & Ebro & HS & 9.87 & October 2000 \\
Talarn & Ebro & HS & 27.83 & November 1999 \\
Flix & Ebro & HS & 3.44 & September 1999 \\
\hline Alarcón & Jucar & HS & 16.26 & September 1999 \\
Tous & Jucar & HS & 34.73 & August 1999 \\
M Cristina & Jucar & HS & 8.62 & September 1999 \\
\hline Crevillente & HS & 13.89 & August 1999 \\
Cenajo & Segura & HS & 27.25 & August 1999 \\
\hline La Granda & Segura & HS & 5.23 & October 2000 \\
Trasona & Horte & HS & 6.72 & October 2000 \\
Villagudín & LS & 10.65 & October 2000 \\
San Cosmade & Norte & LS & 3.60 & October 2000 \\
Belesar & Norte & LS & 35.01 & July 2001 \\
Castrelo & Norte & & 11.79 & July 2001 \\
\hline
\end{tabular}


Table 1.- contin. contin.

\begin{tabular}{|c|c|c|c|c|}
\hline Pontón Alto & Duero & LS & 8.86 & October 2000 \\
\hline Campillo de Buitrago & Duero & LS & 13.30 & August 2001 \\
\hline Cuerda del Pozo & Duero & LS & 10.52 & August 2001 \\
\hline Aguilar & Duero & HS & 13.95 & September 2001 \\
\hline Valparaiso & Duero & LS & 13.77 & September 2001 \\
\hline Ntra.Sra.Agavanzal & Duero & LS & 10.00 & August 2000 \\
\hline Ricobayo & Duero & HS & 19.61 & September 2001 \\
\hline Sta. Teresa & Duero & LS & 18.63 & November 2001 \\
\hline Almendra & Duero & LS & 30.62 & November 2001 \\
\hline Santillana & Tajo & LS & 8.65 & September 2000 \\
\hline Navacerrada & Tajo & LS & 12.15 & August 2000 \\
\hline La Jarosa & Tajo & LS & 12.13 & August 2000 \\
\hline La Tajera & Tajo & HS & 17.11 & July 2000 \\
\hline Valdecañas & Tajo & HS & 19.81 & October 2001 \\
\hline Alcántara & Tajo & LS & 224.07 & October 2001 \\
\hline Zafra & Guadiana & LS & 6.40 & June 1999 \\
\hline Valuengo & Guadiana & LS & 12.87 & June 1999 \\
\hline Brovales & Guadiana & LS & 4.40 & June 1999 \\
\hline Ruecas & Guadiana & LS & 10.07 & September 2000 \\
\hline Peñarroya & Guadiana & HS & 11.65 & August 2001 \\
\hline Gasset & Guadiana & HS & 5.67 & August 2001 \\
\hline La Cabezuela & Guadiana & HS & 6.60 & October 2001 \\
\hline Vega de Jabalón & Guadiana & HS & 5.26 & September 2001 \\
\hline La Serena & Guadiana & LS & 23.17 & October 2001 \\
\hline Huesna & Guadaquivir & LS & 18.29 & August 2000 \\
\hline Sierra Boyera & Guadaquivir & LS & 7.74 & October 2001 \\
\hline Guadalmellato & Guadaquivir & LS & 20.39 & October 2001 \\
\hline
\end{tabular}

Anagnostidis, 1986; Anagnostidis \& Komárek, 1988; Komárek \& Anagnostidis, 1989; Komárek \& Anagnostidis, 1999. We also carried out the required measurements of algae dimensions in order to calculate the biovolume of Cyanobacteria species.

Alkalinity was measured by colorimetric titration (Standard Methods, 1980). Ammonium was analysed using Spectroquant 14752 method (detection limit of the method: $20 \mu \mathrm{gN} / 1$ ). Nitrates were determined using the Spectroquant 14773 method (detection limit: $230 \mu \mathrm{gN} / 1$ ). For nitrites Spectroquant 1477 was used (detection limit: $15 \mu \mathrm{gN} / \mathrm{l})$. Water for total phosphorus analysis was fixed with acid before been analysed back in the laboratory using the ascorbic acid method (detection limit: $10 \mu \mathrm{gP} / 1$ ). Previously, the total phosphorus samples were digested using a DR LANGE HT200S digestor in acidic conditions method (APHA, 1980). Chlorophyll $a$ was determined using the formulas of Parsons \& Strickland (1963).

In some reservoirs nutrient concentration was below the detection limit. As these values are necessary to carry out some analyses (the total inorganic nitrogen / total phosphorus atomic ratio and several regression plots), we have assumed a value of half of this limit (Table 2). The results of the analyses carried out were similar if we consider for phosphorus a value of $9 \mu \mathrm{gP} / 1$ and for nitrates, nitrites and ammonium, $220 \mu \mathrm{gN} / 1,12 \mu \mathrm{gN} / 1$ and $18 \mu \mathrm{gN} / 1$ respectively. 
Table 2.- Chemical parameters and Chlorophyll in 37 Spanish water reservoirs. HS: High solubility rocks; LS: low solubility rock. Concentrations below the detection limit of the analyses method are marked with *; in these cases, the value was assumed as half of this limit (See Materials and Methods). Parámetros químicos y clorofila de 37 embalse españoles. HS: rocas muy solubles; LS: rocas poco solubles. Las concentraciones por debajo del límite de detección del método de análisis se señalan con *; en estos casos hemos considerado como valor la mitad de dicho límite.

\begin{tabular}{|c|c|c|c|c|c|c|c|}
\hline Reservoir & Geological substratum & $\begin{array}{l}\text { Alcalinity } \\
\text { (meq/l) }\end{array}$ & $\begin{array}{c}\mathrm{NH}_{4}^{+} \\
(\mathrm{mg} \mathrm{N} / \mathrm{l})\end{array}$ & $\begin{array}{c}\mathrm{NO}_{2}^{-} \\
(\mathrm{mg} \mathrm{N} / \mathrm{l})\end{array}$ & $\begin{array}{c}\mathrm{NO}_{3}^{-} \\
(\mathrm{mg} \mathrm{N} / \mathrm{l})\end{array}$ & $\begin{array}{c}\text { PT } \\
(\mathrm{mg} \mathrm{P} / \mathrm{l})\end{array}$ & $\begin{array}{c}\text { Chlorophyll } a \\
(\mathrm{mg} / \mathrm{l})\end{array}$ \\
\hline Mansilla & HS & 1.7 & 273 & $7.5^{*}$ & 1390 & 20 & 1.52 \\
\hline Gonzalez Lacasa & HS & 1.46 & 634 & $7.5^{*}$ & $115^{*}$ & 20 & 1.34 \\
\hline Sobrón & HS & 2.08 & $10^{*}$ & $7.5^{*}$ & 1920 & 20 & 4.62 \\
\hline Cereceda & HS & 1.82 & $10^{*}$ & $7.5^{*}$ & 1480 & 30 & 1.41 \\
\hline Urrunaga & HS & 2.44 & 65 & 26 & 1460 & 17 & 1.6 \\
\hline Ullivarri & HS & 2.68 & 54 & 41 & 1890 & 19 & 1.59 \\
\hline Talarn & HS & 2.2 & $10^{*}$ & $7.5^{*}$ & 880 & 20 & 3.05 \\
\hline Flix & HS & 3.78 & $10^{*}$ & 150 & 3590 & 190 & 4.23 \\
\hline Alarcón & HS & 2.92 & $10^{*}$ & 23 & 1400 & 70 & 2.69 \\
\hline Tous & HS & 3.04 & $10^{*}$ & 42 & 1300 & 50 & 0.76 \\
\hline $\mathrm{M}^{\mathrm{a}}$ Cristina & HS & 4.4 & 347 & 67 & 4500 & 50 & 27.92 \\
\hline Crevillente & HS & 3.16 & 41 & 42 & 1940 & 30 & 7.68 \\
\hline Cenajo & HS & 3.66 & $10^{*}$ & 20 & 1710 & 600 & 1.95 \\
\hline La Granda & HS & 3.3 & $10^{*}$ & $7.5^{*}$ & 910 & 23 & 22.69 \\
\hline Trasona & HS & 2.08 & $10^{*}$ & $7.5^{*}$ & $115^{*}$ & 60 & 13.25 \\
\hline La Tajera & HS & 4.4 & 28 & 36 & 780 & 12 & 1.7 \\
\hline Peñarroya & HS & 2.92 & 80 & 20 & $115^{*}$ & $5^{*}$ & 0.84 \\
\hline Gasset & HS & 2.32 & 110 & 40 & $115^{*}$ & 20 & 3.11 \\
\hline La Cabezuela & HS & 3.04 & 70 & $7.5^{*}$ & $115^{*}$ & 15 & 7.85 \\
\hline Vega de Jabalón & HS & 2.68 & 90 & 50 & $115^{*}$ & 60 & 8.24 \\
\hline Villagudín & LS & 0.24 & 59 & 20 & $115^{*}$ & 50 & 13.56 \\
\hline San Cosmade & LS & 0.24 & 66 & 15 & 400 & 10 & 1.8 \\
\hline Belesar & LS & 0.62 & 60 & 20 & $115^{*}$ & 15 & 5.61 \\
\hline Castrelo & LS & 0.6 & 90 & $7.5^{*}$ & $115^{*}$ & 30 & 10.26 \\
\hline Pontón Alto & LS & & 72 & $7.5^{*}$ & 560 & 24 & 10.75 \\
\hline Campillo de Buitrago & LS & 0.61 & 70 & 30 & $115^{*}$ & 40 & 4.68 \\
\hline Cuerda del Pozo & LS & 0.61 & 60 & 20 & $115^{*}$ & 35 & 14.42 \\
\hline Ntra.Sra.Agavanzal & LS & 0.36 & $10^{*}$ & $7.5^{*}$ & 280 & 30 & 11.55 \\
\hline Santillana & LS & 0.74 & 270 & $7.5^{*}$ & $115^{*}$ & 62 & 18.38 \\
\hline Navacerrada & LS & 0.36 & 20 & $7.5^{*}$ & $115^{*}$ & 10 & 2.62 \\
\hline La Jarosa & LS & 0.36 & 20 & $7.5^{*}$ & $115^{*}$ & 10 & 3.42 \\
\hline Zafra & LS & 3.42 & $10^{*}$ & $7.5^{*}$ & $115^{*}$ & 60 & 28.4 \\
\hline Valuengo & LS & 3.9 & 34 & $7.5^{*}$ & 510 & 100 & 32.8 \\
\hline Brovales & LS & 2.8 & 41 & $7.5^{*}$ & 1000 & 170 & 41.9 \\
\hline Ruecas & LS & 0.6 & $10^{*}$ & $7.5^{*}$ & $115^{*}$ & 31 & 5.69 \\
\hline Sierra Boyera & LS & 1.96 & 150 & 80 & $115^{*}$ & 75 & 2. 61 \\
\hline Guadalmellato & LS & 1.82 & 120 & 70 & $115^{*}$ & 15 & 3.21 \\
\hline
\end{tabular}

As a complement to the taxonomic data, 10 more reservoirs were sampled: Ebro, Aguilar, Valparaiso, Ricobayo, Almendra, Santa Teresa,
Alcántara, Valdecañas, La Serena y Huesna. In these cases, the sampling methodology was slightly different. Namely, phytoplankton sam- 
Table 3.- Phytoplankton cell number, cyanobacteria cell number, biovolume of cyanobacteria orders and species found in each reservoir. Numbers indicate the species: 1-Anabaena aphanizomenoides; 2-Anabaena cf. circinalis; 3-Anabaena flos-aquae; 4-Anabaena planctonica; 5-Anabaena cf. sphaerica; 6-Anabaena spiroides; 7-Anabaena sp.; 8-Anabaenopsis circularis; 9-Anabaenopsis sp.; 10-Aphanizomenon gracile; 11-Aphanizomenon flos-aquae; 12-Aphanizomenon sp.; 13-Aphanocapsa elachista; 14-Aphanocapsa cf. holsatica; 15-Aphanothece clathrata; 16-Arthrospira sp.; 17-Chroococcus sp.; 18-Coelosphaerium kuetzingianum; 19-Coelosphaerium sp.; 20-Cylindrospermopsis raciborskii; 21-Cylindrospermopsis sp.; 22-Limnothrix cf. redekei; 23-Limnothrix sp.; 24-Merismopedia warmingiana; 25-Merismopedia sp.; 26-Microcystis aeruginosa; 27-Microcystis cf. flos-aquae; 28-Microcystis ichthyoblabe; 29-Microcystis smithii ; 30-Microcystis wesenbergii; 31-Microcystis sp.; 32-Nostoc cf. gelatinosum; 33-Oscillatoria sp.; 34-Phormidium sp.; 35-Planktolyngbya limnetica; 36-Planktolyngbya sp.; 37-Planktothrix cf. agardhii; 38-Planktothrix cf. prolifica; 39-Pseudanabaena cf. galeata; 40-Pseudanabaena cf. tenuis; 41-Pseudanabaena sp.; 42-Romeria elegans; 43-Romeria leopoliensis; 44-Synechocystis aquatilis; 45-Woronichinia naegeliana. AWB: Administrative water basin; Eb: Ebro; Jc: Jucar; Sg: Segura; N: Norte; Du: Duero; Tj: Tajo;Gu: Guadiana; Gq: Guadaquivir. $N^{o}$ de células del fitoplancton, $n^{o}$ células de cianobacterias, biovolumen de los distintos órdenes de cianobacterias y especies encontradas en cada embalse. Los números indican las especies señaladas arriba. AWB: Cuenca hidrográfica.

\begin{tabular}{|c|c|c|c|c|c|c|c|}
\hline Water reservoir & AWB & $\begin{array}{l}\text { Phytoplankton } \\
\text { cell number } \\
\qquad\left({ }^{*} 10^{3}\right)\end{array}$ & $\begin{array}{l}\text { Cyanobacteria } \\
\text { cell number } \\
\left({ }^{*} 10^{3}\right)\end{array}$ & $\begin{array}{l}\text { Chroococcales } \\
\left(\mathrm{mm}^{3} / \mathrm{m}^{3}\right)\end{array}$ & $\begin{array}{c}\text { Nostocales } \\
\left(\mathrm{mm}^{3} / \mathbf{m}^{3}\right)\end{array}$ & $\begin{array}{l}\text { Oscillatoriales } \\
\left(\mathrm{mm}^{3} / \mathrm{m}^{3}\right)\end{array}$ & Species \\
\hline Ebro & $\mathrm{Eb}$ & 76.7 & 76.0 & 3612.5 & 341 & 0 & $6,7,10,15,17,25,26,28,29,45$ \\
\hline Mansilla & $\mathrm{Eb}$ & 14.4 & 13.4 & 5.9 & 0 & 0 & 15 \\
\hline Gonzalez Lacasa & $\mathrm{Eb}$ & 37.5 & 32.8 & 14.3 & 26.5 & 0 & 7,15 \\
\hline Sobrón & $\mathrm{Eb}$ & 3.6 & 0.7 & 0.6 & 0 & 0 & 15,31 \\
\hline Cereceda & $\mathrm{Eb}$ & 0.9 & 0.015 & 0 & 0 & 0.6 & 33 \\
\hline Urrunaga & $\mathrm{Eb}$ & 2.9 & 2.2 & 2.4 & 0 & 0 & 15,45 \\
\hline Ullivarri & $\mathrm{Eb}$ & 4.7 & 2.9 & 1.1 & 0 & 2.1 & 15,41 \\
\hline Talarn & $\mathrm{Eb}$ & 0.8 & 0 & 0 & 0 & 0 & \\
\hline Flix & $\mathrm{Eb}$ & 8 & 1.1 & 14.4 & 14.8 & 14.8 & $1,18,37,39$ \\
\hline Alarcón & Jc & 12.3 & 7.7 & 3.4 & 0 & 0 & 15 \\
\hline Tous & $\mathrm{Jc}$ & 24.7 & 20.9 & 9.3 & 4.6 & 0 & $7,15,25,31$ \\
\hline $\mathrm{M}^{\mathrm{a}}$ Cristina & $\mathrm{Jc}$ & 557.3 & 463 & 0 & 517.3 & 123106.4 & $9,38,41$ \\
\hline Crevillente & $\mathrm{Sg}$ & 41.3 & 25 & 56.5 & 53.3 & 0 & $7,15,18,31$ \\
\hline Cenajo & $\mathrm{Sg}$ & 13.9 & 8.6 & 3.7 & 5 & 0 & $7,15,41$ \\
\hline La Granda & $\mathrm{N}$ & 3 & 0.1 & 2.1 & 6.1 & 0 & 7,26 \\
\hline Trasona & $\mathrm{N}$ & 12.1 & 9.7 & 629.8 & 22.1 & 0.8 & $6,26,30,41$ \\
\hline Villagudín & $\mathrm{N}$ & 14.8 & 3.6 & 79.3 & 0.9 & 0 & $7,15,45$ \\
\hline San Cosmade & $\mathrm{N}$ & 1.2 & 0.1 & 5.8 & 0 & 0 & 45 \\
\hline Belesar & $\mathrm{N}$ & 76.1 & 66.6 & 29.4 & 0 & 0 & 15 \\
\hline Castrelo & $\mathrm{N}$ & 25.5 & 0.5 & 0 & 13.9 & 7.2 & $10,34,40$ \\
\hline Pontón Alto & $\mathrm{Du}$ & 7.4 & 2.4 & 95.2 & 0 & 0 & 45 \\
\hline Campillo de Buitrago & $\mathrm{Du}$ & 14.3 & 4.5 & 1.7 & 154.1 & 0 & $4,10,15,24,30$ \\
\hline Cuerda del Pozo & $\mathrm{Du}$ & 45.8 & 43.4 & 5.2 & 6195.8 & 0 & $4,6,10,15,24$ \\
\hline Aguilar & $\mathrm{Du}$ & 3.9 & 3.1 & 4.3 & 182.2 & 0 & $6,10,15,30$ \\
\hline Valparaiso & $\mathrm{Du}$ & 28.3 & 24 & 8.9 & 1931.5 & 0 & $2,15,25,31$ \\
\hline Ntra.Sra.Agavanzal & $\mathrm{Du}$ & 3.6 & 1 & 0.4 & 0 & 0 & 15 \\
\hline Ricobayo & $\mathrm{Du}$ & 6.3 & 5.3 & 134.4 & 184.2 & 0 & $2,3,12,31,45$ \\
\hline Sta. Teresa & $\mathrm{Du}$ & 27.5 & 20.1 & 770.3 & 12.1 & 0 & $2,10,45$ \\
\hline Almendra & $\mathrm{Du}$ & 14 & 13.6 & 1184.9 & 0 & 0 & 30 \\
\hline Santillana & $\mathrm{Tj}$ & 21.8 & 12.6 & 6.1 & 3.8 & 0 & $12,15,19,32$ \\
\hline Navacerrada & $\mathrm{Tj}$ & 37.8 & 30.9 & 52.6 & 109.1 & 0 & $7,11,15,26,45$ \\
\hline La Jarosa & $\mathrm{Tj}$ & 2.3 & 0.4 & 13.3 & 9.5 & 0 & $5,6,15,45$ \\
\hline La Tajera & $\mathrm{Tj}$ & 51.6 & 35 & 14.7 & 0 & 32.5 & 15,37 \\
\hline Valdecañas & $\mathrm{Tj}$ & 51.3 & 50.6 & 2822.2 & 0 & 158 & $16,22,25,26,30,33,43$ \\
\hline Alcántara & $\mathrm{Tj}$ & 10.7 & 9.5 & 123.6 & 0 & 131.2 & $22,29,30,43$ \\
\hline
\end{tabular}


Table 3.- cont. contin.

\begin{tabular}{|c|c|c|c|c|c|c|c|}
\hline Zafra & $\mathrm{Gu}$ & 46.4 & 1.1 & 51.7 & 55.5 & 0 & $7,10,17,18$ \\
\hline Valuengo & $\mathrm{Gu}$ & 672.3 & 662 & 0 & 37809.6 & 115.3 & $1,9,10,20,23$ \\
\hline Brovales & $\mathrm{Gu}$ & 1021.2 & 1008 & 14.1 & 46126.2 & 0 & $1,18,20,25$ \\
\hline Ruecas & $\mathrm{Gu}$ & 68.6 & 55.9 & 452.7 & 15 & 0 & $10,15,26,31$ \\
\hline Peñarroya & $\mathrm{Gu}$ & 7.2 & 0.1 & 0.4 & 0 & 0.2 & 41,44 \\
\hline Gasset & $\mathrm{Gu}$ & 92 & 88.2 & 49.4 & 2 & 0 & $7,14,31,41,45$ \\
\hline La Cabezuela & $\mathrm{Gu}$ & 17 & 13.6 & 7.1 & 0 & 0 & 24 \\
\hline Vega de Jabalón & $\mathrm{Gu}$ & 566.6 & 559.7 & 34.7 & 1616.2 & 6315.8 & $1,8,10,14,21,36,37,41$ \\
\hline La Serena & $\mathrm{Gu}$ & 13.8 & 11.4 & 417.2 & 19.3 & 0 & $7,10,25,42,45$ \\
\hline Huesna & $\mathrm{Gq}$ & 357.7 & 347.5 & 221.6 & 3690.3 & 13.4 & $4,6,11,15,27,35$ \\
\hline Sierra Boyera & $\mathrm{Gq}$ & 24.8 & 9.5 & 76.4 & 36.7 & 151.9 & $1,12,13,17,18,37,44$ \\
\hline Guadalmellato & $\mathrm{Gq}$ & 26 & 25 & 90.8 & 1505.1 & 0 & $4,10,44,45$ \\
\hline
\end{tabular}

ples from the whole euphothic zone were combined. In these water reservoirs the chemical parameters were not analysed.

All the samplings and chemical analyses were carried out by CEDEX (Centro de Estudios y Experimentación de Obras Públicas - PublicWorks Study and Research Centre) staff.

\section{RESULTS AND DISCUSSION}

\section{Abundance and distribution of Cyanobacteria}

Table 3 shows the quantity (expressed as biovolume) of each of the three Cyanobacteria groups: Chroococcales, Nostocales and Oscillatoriales, found in the 47 studied water reservoirs. The reservoirs of the Duero, Tajo, Guadiana and Guadalquivir basins contained the highest amounts of Cyanobacteria (Fig. 2). Conversely, only three of the remaining reservoirs (Ebro, $\mathrm{M}^{\mathrm{a}}$ Cristina, and Trasona situated respectively in Ebro, Jucar and a northern river basins) had significant amounts of Cyanobacteria (Table 3). Dasí et al., 1998, found comparable results for the Jucar basin. However, some Cyanobacteria blooms (especially of Microcystis aeruginosa) have been reported for a part of northern-river basins: in the sector of river Miño shared by Spain and Portugal (Vasconcelos \& Cerqueira, 2001).

Quantitative total phytoplankton parameters are shown in Tables 2 and 3. These parameters have positive and high significant correlation with cyanobacteria cell number (the correlation coefficient with chlorophyll and phytoplankton cell number was respectively $r=0.53, p=0.0001$ and $\mathrm{r}=0.9, \mathrm{p}=0.0000)$ and cyanobacteria biovolume (the correlation coefficient with chlorophyll and phytoplankton cell number was respectively $\mathrm{r}=0.5, \mathrm{p}=0.0004$ and $\mathrm{r}=0.66, \mathrm{p}=0.0000$ ). Some reservoirs (Table 3) show relatively high phytoplankton and cyanobacteria cell number but low cyanobacteria biovolumen (for example Belesar) due to the presence of small-cell species (for example Aphanothece clathrata).

The correlations between total phosphorus and the parameters related to phytoplankton quantity (logarithm transformed: $\ln \mathrm{x}$ ) were: $\mathrm{r}=$ $0.603, p=0.00015$ for chlorophyll and $r=0.58$, $\mathrm{p}=0.0002$ for cell number. A positive relationship between total phosphorus and chlorophyll has been reported in the Spanish water reservoirs in earlier limnological studies (Ortiz Casas \& Peña Martínez, 1984; Morguí et al., 1990; Riera et al., 1992; Dasi et al., 1998). The correlation between total phosphorus and Cyanobacteria (logarithm transformed: $\ln \mathrm{x}$ ) was also significant for biovolume: $r=0.58$, $\mathrm{p}=0.0001$ (Fig. 3) and for cell number $\mathrm{r}=0.49$ and $\mathrm{p}=0.004$. The association between Cyanobacteria blooms and eutrophication had been reported before (Wetzel, 1975; Reynols \& Walsby, 1975). If Cyanobacteria are present, enhanced phosphorus concentrations will support enhanced growth (Reynolds \& Petersen, 2000). However, apart from phosphorus, a com- 


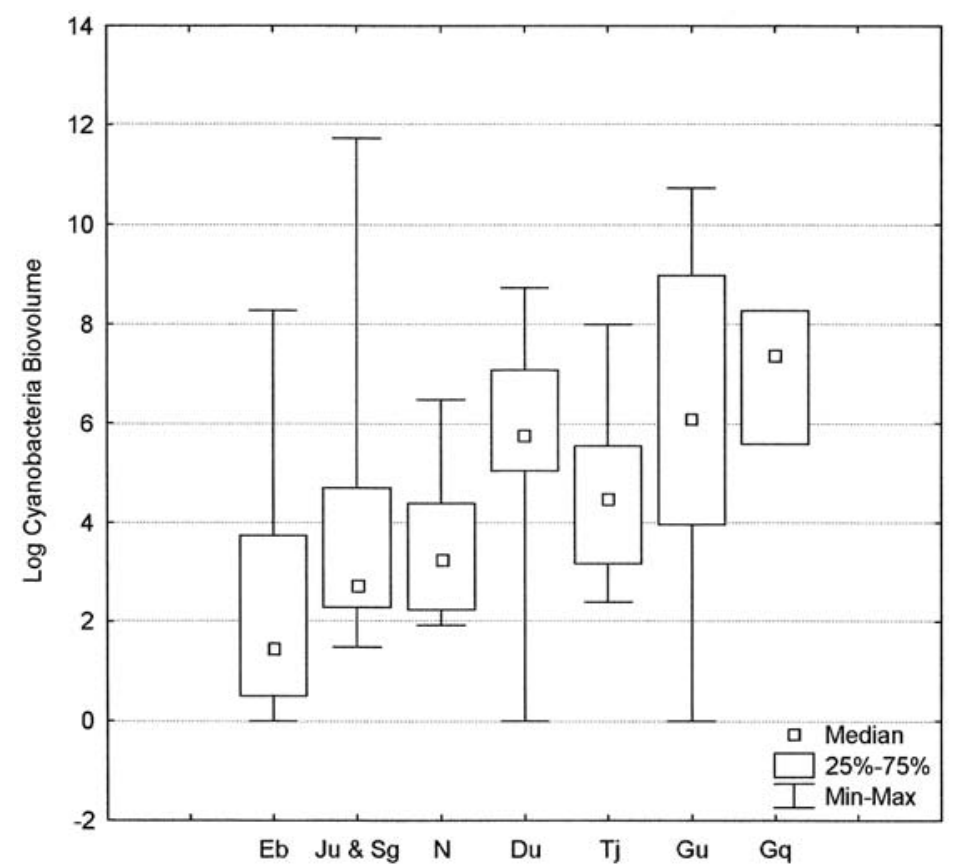

Figure 2. Box-plots of Cyanobacteria biovolume in administrative Spanish water basins. Logarithmic transformed data: $1 n(x+1)$. Eb: Ebro; Jc: Jucar; Sg: Segura; N: Norte; Du: Duero; Tj: Tajo;Gu: Guadiana; Gq: Guadaquivir. Diagramas Box-plots del biovolumen de cianobacterias. Datos transformados logaritmicamente: $\ln (x+1)$

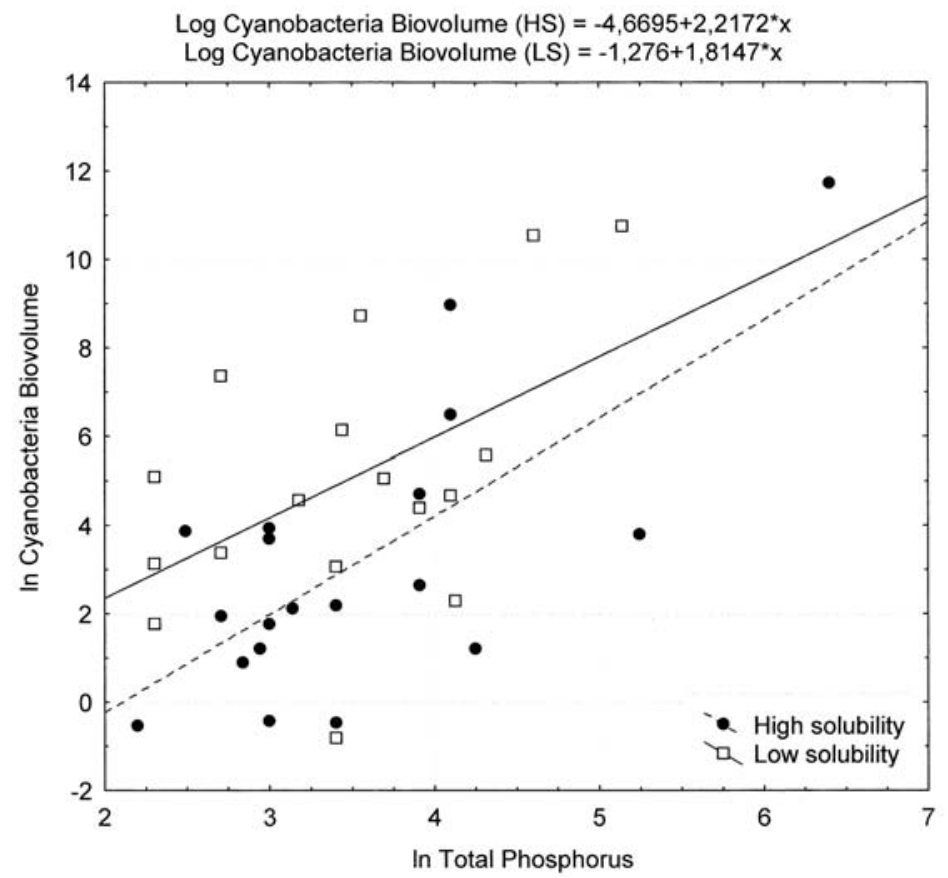

Figure 3. Regression plot between Cyanobacteria biovolume and total phosphorus, both logarithm transformed (ln). The studied water reservoirs are divided in two groups: those situated on low solubility rocks and those on high solubility rocks (figure 1). Gráfica de regresión entre el biovolumen de cianobacterias y el fósforo total, ambos transformados logaritmicamente (ln). Se diferencian dos grupos de embalses: los situados sobre rocas de baja solubilidad y aquellos situados sobre rocas de alta solubilidad (ver figura 1). 
plex of physical and chemical conditions influence Cyanobacterial growth (Reynols \& Walsby, 1975; Steinberg \& Hartmann, 1988). Figure 3 shows two regression plots between Cyanobacteria biovolume and total phosphorus in water reservoirs with different rock types in the catchment area. These two types of areas are shown in figure 1; the broken line separates the western areas with rocks of low solubility (plutonic or metamorphic) generally situated on the Hesperic Massif (Capote, 1983) from those with rocks of high solubility (generally sedimentary) not on the Hesperic Massif. In figure 3, the water reservoirs situated in these two areas, are marked with different symbols. Under conditions of the same amount of total phosphorus, cyanobacteria growth is higher in the western area. This is related to the poor concentration of nitrates and lower N/P ratio found in this area, as is shown below.

Cyanobacteria were present in large quantities when $\mathrm{N}$ was the primary-production limiting factor. Figure 4 shows that the reservoirs with Cyanobacteria biovolume higher than 200 $\mathrm{mm}^{3} / \mathrm{m}^{3}(\ln =5.2)$ had the atomic ratio of TIN/TP (total inorganic nitrogen/total phosphorus) lower than 50. The atomic ratio of N:P in phytoplankton generally varies between 15 and 22 (Downing \& McCauley, 1992). Smith (1982) suggested that $\mathrm{N}$ could be limiting to algal growth when the atomic ratio of total nitrogen to total phosphorus (TN:TP) in the water falls bellow an optimum level (64). In that case, $\mathrm{N}_{2}$-fixing Cyanobacteria would have ecological advantage over other algae. Quesada \& Valiente (1996) reported the relationship between $\mathrm{N}_{2}$ fixing cyanobacteria and low N/P ratio in their

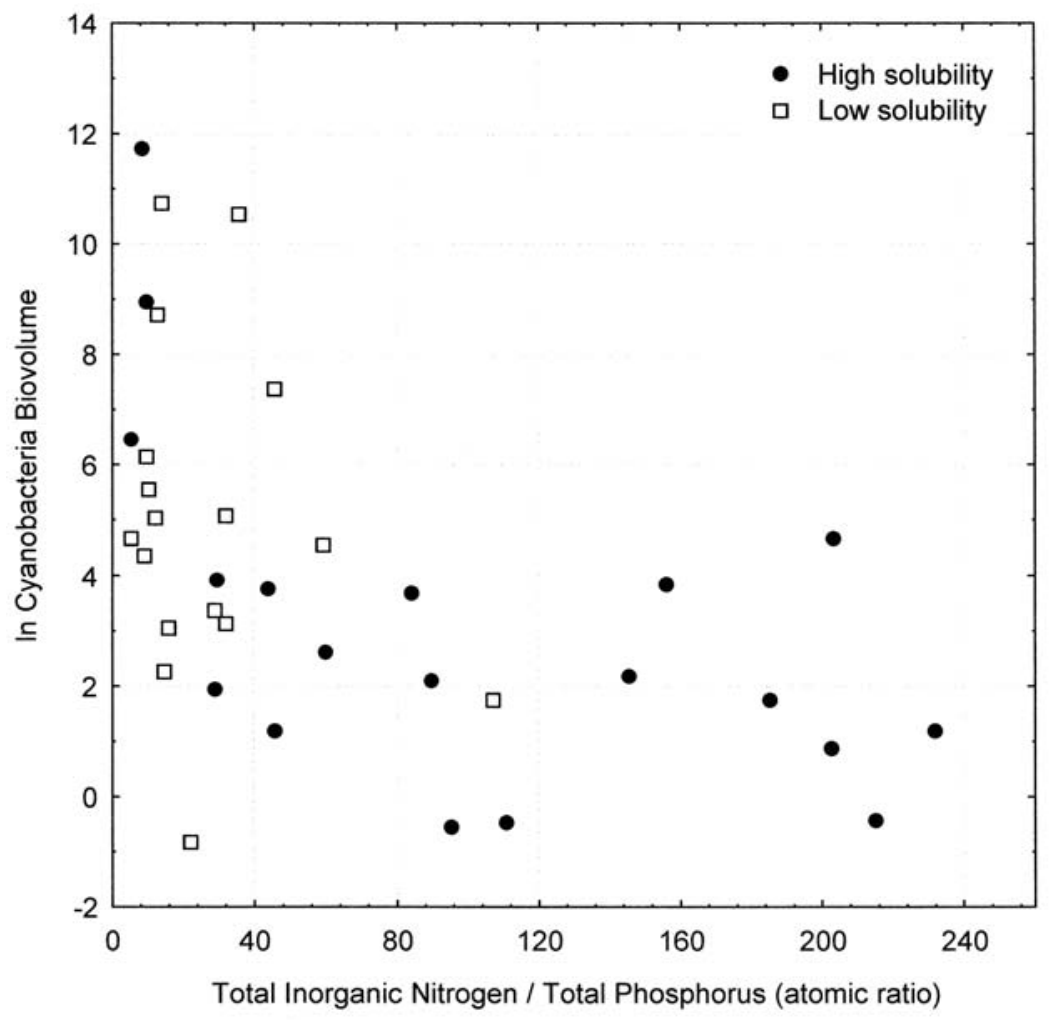

Figure 4. The relationship between Cyanobacteria biovolume, logarithm transformed (ln) and the TIN:TP atomic ratio (total inorganic nitrogen: total phosphorus atomic ratio). The studied water reservoirs are divided in two groups: those situated on low solubility rocks and those on high solubility rocks (figure 1). Relación entre el biovolumen de cianobacterias, transformado logaritmicamente (ln) y la relación atomica NIT:TP (nitrógeno inorgánico total/ fósforo total). Se diferencian dos grupos de embalses: los situados sobre rocas de baja solubilidad y aquellos situados sobre rocas de alta solubilidad (ver figura 1). 


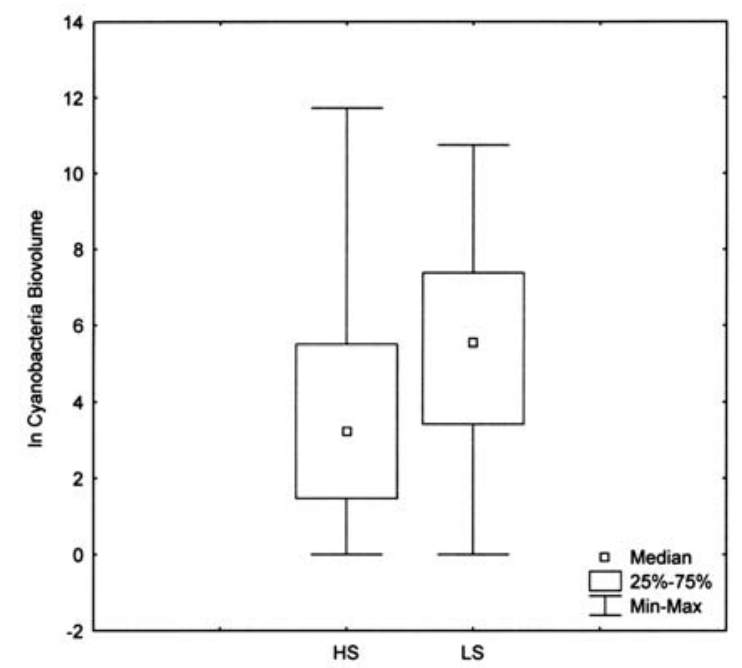

Figure 5. Box-plots of Cyanobacteria biovolume logarithm transformed: $\ln (x+1)$, in reservoir situated on low solubility rocks (LS) and on high solubility rocks (HS) (figure 1). Diagramas Box-plots del biovolumen de cianobacterias, transformado logarítmicamente: In $(x+1)$, en embalses situados sobre rocas de baja solubilidad (LS) y sobre rocas de alta solubilidad (HS) (ver figura 1).

studies on Spanish rice fields. The fixation of atmospheric nitrogen $\left(\mathrm{N}_{2}\right)$ to ammonia is catalysed by nitrogenase in specialised cells termed heterocysts (Paerl, 1988). However, it has been proven that some non-heterocystous Cyanobacteria can also fix $\mathrm{N}_{2}$ (Carpenter \& Prince, 1976; Zehr et al., 2000; Zehr et al., 2001). In figure 4, the water reservoirs situated in the two areas shown in figure 1 are marked with different symbols. Most reservoirs located in areas on rocks of low solubility had very low TIN:TP ratio. Waters situated on more soluble rocks have higher $\mathrm{N}: \mathrm{P}$ ratio due to the higher $\mathrm{NO}_{3}{ }^{-}$concentration and higher alkalinity (table 2). The higher alkalinity leads to the removal of phosphorus by precipitation with calcium. Previous studies (Estrada, 1978; Riera et al., 1992) carried out in 100 Spanish reservoirs also conclude that the concentration of nitrate was correlated with the water mineral content and Margalef et al. (1976) found means of the atomic $\mathrm{N}-\mathrm{NO}_{3}{ }^{-}: \mathrm{P}^{-} \mathrm{PO}_{4}{ }^{3-}$ ratio close to 20 for the siliceous part of Spain and about 100 for the calcareous one. In our study, reservoirs situated on the low solubility rocks of the western part of Spain, with low
TIN:TP ratio, contained more cyanobacteria than the ones situated in the east part (Fig. 5). This was especially manifest in Nostocales, Cyanobacteria with heterocysts (Fig. 6). In figure 1 the water reservoirs are classified in two groups: those with Cyanobacteria biovolume higher and lower than $200 \mathrm{~mm}^{3} / \mathrm{m}^{3}$. Most of the former ones are situated in the western part of Spain.

Riera et al. (1992) found that alkalinity influenced the amount of phytoplankton in the Spanish water reservoirs. In a multivariant analysis, it was the second factor, after total phosphorus, affecting the summer epilimnetic chlorophyll-a. Planas (1975) suggested that there could be a relationship between the phytoplankton communities found in the water reservoirs in both geological areas and the N:P ratio. Our study confirms this hypothesis, as regards to Cyanobacteria. Thus, the west part of Spain would be more prone to present problems arising from Cyanobacteria proliferation than the eastern one.

Our results are also in agreement with those of Smith (1983), who showed that the proportion of Cyanobacteria in phytoplankton was related to TN:TP ratio in 17 lakes around the world. He found that Cyanobacteria tended to be scarce when this atomic ratio exceeded 64:1. Reynolds \& Petersen (2000) found that the distribution of bloom-forming Cyanobacteria in Ireland was strongly related to catchment geology; but, contrary to our results, they mainly occurred in productive calcareous lakes. It could be due to the selective advantage of these organisms in $\mathrm{CO}_{2}$-limited environments, as it occurs in some calcareous and productive waters (Reynolds \& Petersen, 2000).

\section{Species composition}

Table 3 lists 45 taxa found in our study and shows the reservoirs where they occurred. Many of these species (Anabaena circinalis, Anabaena flos-aquae, Anabaena planctonica, Anabaena spiroides, Aphanizomenon flos-aquae, Microcystis aeruginosa, Planktothrix agardhii, Cylindrospermopsis raciborskii and Woronichinia naegeliana) are able to produce toxins 


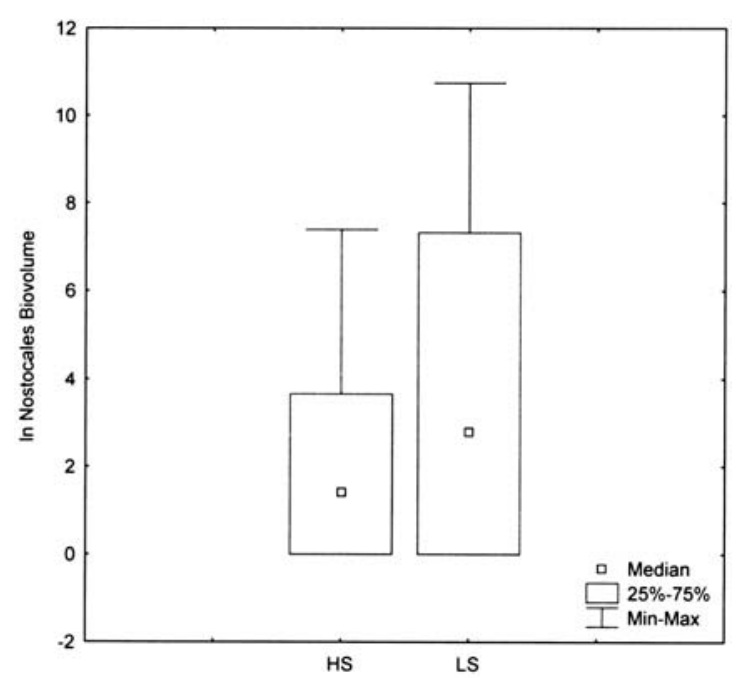

Figure 6. Box-plots of Nostocales biovolume logarithm transformed: $\ln (x+1)$, in reservoir situated on low solubility rocks (LS) and on high solubility rocks (HS) (figure 1). Diagramas Box-plots del biovolumen de cianobacterias nostocales, transformado logarítmicamente: In $(x+1)$, en embalses situados sobre rocas de baja solubilidad (LS) y sobre rocas de alta solubilidad (HS) (ver figura 1).

(Sivonen \& Jones, 1999; Cronberg et al., 1999). A large number of toxin-producing species have been reported recently. Thus, possibly some other species listed in our table could be classified as toxin-producing ones in the future.

Only three species (Anabaena circinalis, Anabaena spiroides and Aphanothece clathrata) of Table 3 are also in the list of 31 Cyanobacteria species reported by Margalef et al. (1976) after a study of 100 Spanish water reservoirs in 1972-74 using sedimented-phytoplankton samples. They also analysed net samples reporting two more species (Anabaena flosaquae and Microcystis aeruginosa) which were recorded in our study. Another study carried out fifteen years later (in 1987-88) in the same 100 reservoirs, served to report 11 Cyanobacteria species (Sabater \& Nolla, 1991). Four of them (Anabaena planctonica, Anabaena spiroides, Aphanizomenon flos-aquae and Microcystis aeruginosa) coincide with those in our study.

Some different species recorded in these three works (Margalef, et al, 1976; Sabater \& Nolla; 1991 and this paper) could actually be the same species. For example, Anabaena scheremetievi found in 1972-74 probably is A. planctonica found by us and also reported by Sabater \& Nolla (1991). The name A. scheremetievi was usually designated to the species which is now correctly known as A. planctonica (Komarek, personal communication). However, although the slight similarity between the three Cyanobacteria lists is partly due to taxonomic problems, there is no doubt that there has been considerable variation in Cyanobacterial flora in Spanish water reservoirs in the last 27 years.

The species of the genera Microcystis (Microcystis cf. flos-aquae, Microcystis ichthyoblabe, Microcystis smithii, M. wesenbergii), Aphanizomenon (Aphanizomenon gracile, Aphanizomenon flos-aquae, Aphanizomenon sp.), Anabaenopsis (Anabaenopsis circularis, Anabaenopsis sp.) or Cylindrospermopsis (Cylindrospermopsis raciborskii, Cylindrospermopsis sp.) found in our study are not mentioned in that of Margalef et al. They often occur in "blooms" and in certain situations produce toxins. Some of these species were also reported in studies carried out in recent years: Aphanizomenon flos-aquae (Armengol et al., 1990; Sabater \& Nolla, 1991; Arauzo \& Alvarez Cobelas, 1994) and Anabaenopsis circularis (Dasí et al., 1998).

The genus Cylindrospermopsis has not been reported in Spanish reservoirs in previous works but it is present in Albufera of Valencia (a shallow hypertrophic lake located in the S-E of Spain) (Romo \& Miracle, 1994). It has tropical or subtropical origin (Reynolds, 1987), but now is rapidly expanding its geographical area (Padisák, 1997). Its invasive success challenges eutrophication control in many lakes (Isvánovics et al., 2000). We found this genus in three very eutrophic reservoirs in the Guadiana basin (Valuengo, Brovales and Vega de Jabalón). This genus can produce hepatotoxic alkaloids (Sivonen \& Jones, 1999).

Sabater \& Nolla (1991) observed an increase in the number of eutrophic phytoplankton species as compared to the first sampling of the Spanish reservoirs made by Margalef et al. (1976), as well as an increase in the growth of 
some Cyanobacteria belonging to Anabaena, Microcystis, and Aphanizomenon genera. Likewise, our study shows an increase in species number and quantity of Cyanobacteria as well as in the appearance of genera producing toxins, which cause increment problems in the management and maintenance of water reservoirs.

\section{ACKNOWLEDGMENTS}

This study was carried out within the framework of collaboration agreements between CEDEX and the University of Salamanca for the study of phytoplankton in water reservoirs. We would like to thank CEDEX for contributing the physical and chemical data.

\section{BIBLIOGRAPHY}

ALVAREZ COBELAS, M. \& M. ARAUZO. 1994. Phytoplankton responses to varying time scales in a eutrophic reservoir. Arch. Hydrobiol. Ergebn Limnol., 40: 69-80.

ANAGNOSTIDIS, K. \& J. KOMAREK. 1988. Modern approach to the classification system of cyanophytes. 1. Oscillatoriales. Arch. Hydrobiol. (Algol.Stud. 50-53), Suppl., 80 (1-4): 327-472.

APHA. 1980. Standard Methods for the Examination of Water and Wasterwater, 15th ed. Amer.Publ. Health Ass. N.Y.

ARAUZO, M. \& M. ALVAREZ COBELAS. 1994. Respuesta de la comunidad fitoplanctónica a la estacionalidad en un embalse eutrófico. Limnetica 10 (1):37-42.

ARMENGOL, J., J. CATALÁN, N. GABELLONE, D. JAUME, J. DE MANUEL, E. MARTÍ, J. A. MORGUÍ, J. NOLLA, J. PEÑUELAS, M. REAL, J. L. RIERA, S. SABATER, F. SABATER \& J. TOJA. 1990. A comparative limnological study of the Guadalhorce reservoirs system (Málaga, S.E. Spain). Sciencia Gerundensis, 16 (2): 27-41.

ARMENGOL, J., J. L. RIERA \& J. A. MORGUÍ. 1991. Major ionic composition in the Spanish reservoirs. Verh. Internat. Verein. Limnol. 24: 1363-1366.

BIANCHI, T. S., E. ENGELHAUPT; P. WESTMAN ; T. ANDRÉN, C. ROLFF \& R.
ELMGREN. 2000. Cyanobacterial blooms in the Baltic Sea: Natural or human-induced?. Limnol. Oceanogr., 45(3): 716-726.

BLOMQVIST,P. P.; A. PETTERSSON \& P. HYENSTRAND. 1994. Ammonium-nitrogen: A key regulatory factor causing dominance of non-nitrogenfixing cyanobacteria in aquatic systems. Arch. Hydrobiol. ,132 (2): 141-164.

CANFIELD, D. E., JR. E. PHLIPS \& C. M. DUARTE. 1989. Factors influencing the abundance of blue-green algae in Florida lakes. Can. J. Fish Aquat. Sci., 46: 1232-1237.

CAPOTE, R., 1983. La evolución tardihercínica. En J.M. Ríos ed. Geología de España. Instituto Geológico y Minero de España. Madrid.

CARPENTER E. J. \& C. C. PRICE. 1976. Marine Oscillatoria (Trichodesmium): explanation for aerobic nitrogen fixation without heterocysts. Science, 191: 1278-1280.

CRONBERG, G., H. ANNADOTTER \& L. A.LAWTON. 1999. The occurrence of toxic blue-green algae in Lake Ringsjön, southern Sweden, despite nutrient reduction and fish biomanipulation. Hidrobiología, 404: 123-129.

DASÍ, M. J., M. R. MIRACLE, A. CAMACHO, J. M. SORIA \& E. VICENTE. 1998. Summer phytoplankton assemblages across trophic gradients in hard-water reservoirs. Hydrobiologia 369/370: 27-43.

DESIKACHARY, T. V. 1959. Cyanophyta. Indian Council of Agricultural Research ed. New Delhi.

DE HOYOS, C. 1996., Limnología del lago de Sanabria. Variabilidad interanual del fitoplancton. Tesis doctoral. Universidad de Salamanca. 438 pp.

DE HOYOS, C., F. COMÍN, J. J. ALDASORO \& J. C. VEGA. 2000. Las cianofíceas en el lago de Sanabria: significado y variabilidad estacional. En: Conservación de lagos y humedales de alta montaña de la Península Ibérica. I. Granados \& M. Toro (eds.). UA Ediciones. Colección de estudios $n^{\circ} 63: 131-142$.

DOWNING J. A. \& E. MCCAULEY. 1992. The nitrogen: phosphorus relationship in lakes. Limnol. Oceanogr., 37(5): 936-945.

ESTRADA, M. 1978. Relationships among biological and physicochemical parameters in Spanish reservoirs. Verh. Internat. Verein. Limnol., 20: 1642-1646.

GEITLER, L. 1932. Cyanophyceae. In: Rabenhorst's Kryptogamenflora von Deutschland, Österreich und der Schweiz 14. Akad. Verlagsges. Leipzig. 
ISVÁNOVICS, V., H. M. SHAFIK, M. PRÉSING \& S. JUHOS. 2000. Growth and phosphate uptake kinetics of the cyanobacterium Cylindrospermopsis raciborskii (Cyanophyceae) in throughflow cultures. Freshwater Biology, 43: 257-275.

KOMÁREK, J \& K. ANAGNOSTIDIS. 1986. Modern approach to the classification system of cyanophytes. 2. Chroococcales. Arch. Hydrobiol. (Algol. Stud. 43) Suppl., 73 (2): 157-226.

KOMÁREK, J \& K. ANAGNOSTIDIS. 1989. Modern approach to the classification system of cyanophytes. 4. Nostocales. Arch. Hydrobiol. (Algol. Stud. 56) Suppl., 82: 3247-345.

KOMÁREK, J. \& K. ANAGNOSTIDIS. 1999. Sübwasserflora von Mitteleuropa Band 19/1. Cyanoprokaryota. 1. Teil: Chroococcales. H. Ettl, G. Gärtner, H. Heynig \& D. Mollenhauer (eds.) Berlin.

MARGALEF, R., M. D. PLANAS, J. ARMENGOL, A. VIDAL, N. PRAT, A. GUISSET, J. TOJA \& M. ESTRADA. 1976. Limnología de los embalses españoles. Dirección General de Obras Hidraúlicas. M.O.P. Publ. 123. Madrid.

MORGUI, J. A., J.ARMENGOL \& J. L. RIERA. 1990. Evaluación limnológica del estado de los embalses españoles: composición iónica y nutrientes. Comunicaciones de las Terceras Jornadas Españolas de Presas. Barcelona.

NEGRO, A. I., C. DE HOYOS \& J. C. VEGA. 2000. Phytoplankton structure and dynamics in Lake Sanabria and Valparaíso reservoir (NW Spain). Hydrobiologia, 424: 25-37.

ORTIZ CASAS, J. L. \& R. PEÑA MARTÍNEZ. 1984. Applicability of the OECD eutrophication models to Spanish reservoirs. Verh. Internat. Verein. Limnol., 22: 1521-1535.

PADISÁK, J. 1997. Cylindrospermopsis raciborskii (Woloszynska) Seenayya et Subba Raju, an expanding highly adaptive cyanobacterial species: geographic distribution, population dynamics and autecology. Archiv für Hydrobiologie, Suppl. 107: 563-593.

PAERL, H. 1988. Growth and reproductive strategies of freshwater blue-green algae (Cyanobacteria). In: Growth and reproductive strategies of freshwater phytoplankton. C.D. Sandgren (ed.). Cambridge University Press. Cambridge.

PARSON, T. R. \& J. D. H. STRICKLAND. 1963. Discussion of spectrophotometric determination of marine plant pigments, with revised equations for ascertaining chlorophyll and carotenoids. $J$. Mar. Res., 21: 155-163.

PLANAS, D. 1975. Distribution and productivity of the phytoplankton in Spanish reservoirs. Verh. Internat. Verein. Limnol., 19: 1860-1870.

QUESADA, A. E. FERNÁNDEZ-VALIENTE. 1996. Relationship between abundance of $\mathrm{N}_{2}$-fixing Cyanobacteria and environmental features of Spsnish rice fields. Microb. Ecol., 32: 59-71.

RAMÓN, G. \& G. MOYÁ. 1984. Seasonal variations in the vertical distribution of Oscillatoria rubescens D.C. in the Gorg Blau reservoir, Spain. Verh. Internat. Verein. Limnol., 22: 1546-1549.

REYNOLDS, C. S. 1987. Cyanobacterial WaterBlooms. Adv. Bot. Res., 13: 67-142.

REYNOLDS, C. S. \& A. E. WASBY. 1975. Water blooms. Biol.Rev., 50: 437-481.

REYNOLDS, C. S. \& A. C. PETERSEN. 2000. The distribution of planktonic Cyanobacteria in Irish lakes in relation to their trophic states. Hydrobiologia, 424: 91-99.

RIERA, J. L.; D. JAUME, J. DE MANUEL, J. A. MORGUI \& J. ARMENGOL. 1992. Patterns of variation in the limnology of Spanish reservoirs: a regional study. Limnetica, 8: 111-123.

ROMO, S. \& M. R. MIRACLE. 1994. Population dynamics and ecology of subdominant phytoplankton species in a shallow hypertrophic lake (Albufera de Valencia, Spain). Hydrobiologia, 273: 37-56.

SABATER, S. \& J. NOLLA. 1991. Distributional patterns of phytoplankton in Spanish reservoirs: First results and comparison after fifteen years. Verh. Internat. Verein. Limnol., 24: 1371-1375.

SHAPIRO, J. 1990. Current beliefs regarding dominance by blue-greens. The case for the importance of $\mathrm{CO}_{2}$ and $\mathrm{pH}$. Int. Vereinigung Theor. Limnol. Verh., 24: 38-54.

SIVONEN, K. \& G. JONES. 1999. Cyanobacterial toxins. In: Toxic Cyanobacteria in Water. A guide to their public health consequences, monitoring and management. I. Chorus \& J. Bartram (eds.): 41-111. New York.

SOURNIA, J. 1978. Phytoplankton manual. UNESCO. París.

SMITH, V. H. 1982. The nitrogen and phosphorus dependence of algal biomass in lakes: An empirical and theoretical analysis. Limnol. Oceanogr., 27: 1101-1112.

SMITH, V. H. 1983. Low nitrogen to phosphorus ratios favour dominance by blue-green algae in lake plankton. Science, 221: 669-971. 
STEINBERG, C. E. W. \& H. M. HARTMANN. 1988. Planktonic bloom-forming Cyanobacteria and the eutrophication of lakes and rivers. Freshwater Biology, 20: 279-287.

TOJA, J. 1980. Limnología del embalse de La Minilla durante 1976. I. Ciclo del fitoplancton en relación con los factores del medio. Oecologia aquatica, 4: 71-88.

TOJA, J. 1984. Limnología de los embalses para el abastecimiento de aguas a Sevilla. CEDEX. M.O.P.U. Publ. 145. Madrid.

VASCONCELOS, V. \& M. CERQUEIRA. 2001. Phytoplankton community of river Minho (International section). Limnetica, 20 (1): 135141.
VIDAL-CELMA, A. 1969. Evolution d'un lac de barrage dans le NE de 1'Espagne pendant les quatre premières années de service. Verh. Internt. Verein. Limnol., 17: 191-200.

WETZEL, R. G. 1975. Limnología. Ediciones Omega. Barcelona.

ZEHR, J. P., E. J., CARPENTER \& T. A. VILLAREAL. 2000. New perspectives on nitrogen-fixing microorganisms in tropical and subtropical oceans. Trends in Microbiology, 8 (2): 68-73.

ZEHR, J. P., J. B., WATERBURY, P. J. TURNER, J. P. MONTOYA, E. OMOREGIE, G. F. STEWARD, A. HANSEN \& D. M. KARL. 2001. Unicellular cyanobacteria fix N2 in the subtropical North Pacific Ocean. Nature, 412: 635-638. 